\title{
California increases support for agricultural easements
}

\section{A $S$ urban develop- AS ment continues its} creep into agricultural areas, California is stepping up efforts to protect farmland with conservation easements, which let landowners sell their nonagricultural development potential in perpetuity (in effect, forever). In 1996, the state established the California Farmland Conservancy Program (CFCP) to protect farmland by buying easements. In 2000 , voters provided \$25 million for agricultural protection by approving Proposition 12 , the $\$ 2.1$ billion parks bond. And in March 2002, voters could increase the total dramatically by approving Proposition 40 , a $\$ 2.6$ billion parks bond that could provide an additional \$75 million to conserve agricultural land.

There are several other ways that farmland can be protected from residential or commercial development, such as outright purchase by conservation organizations or restrictive zoning ordinances. While conservation easements have traditionally targeted natural resource areas, over the past 20 years they have been increasingly used to protect agriculture in California and elsewhere.

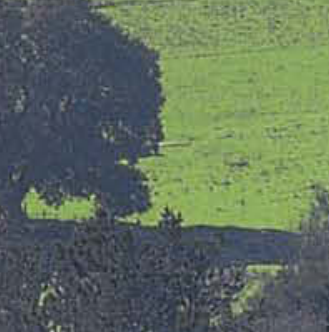

"The trend at the state level is to expand funding for conservation easements," says UC Cooperative Extension public policy specialist $\mathrm{Al}$ Sokolow, noting that funding these easements at the local level is limited by tax restrictions and the scarcity of private donors.

\section{Working farms targeted}

Originally called the Agricultural Land Stewardship Program, the CFCP is the only statewide program dedicated to protecting farmland with conservation easements. While two state agencies (the Coastal Conservancy and Wildlife Conservation Board) can also fund easements, they tend to focus on open space and wildlife habitat rather than keeping farmland in active production.

To date, the CFCP has awarded about $\$ 16$ million to fund 50 agricultural easements that protect more than 13,000 acres. An additional \$14 million in matching funds came from other sources, including landowner donations, the federal Farmland Protection Program and private foundations.

The CFCP currently receives $\$ 1.5$ million per year from the state general fund and about $\$ 5$ million per year from Proposition 12, which will continue to fund conservation easements through 2003, CFCP manager Charles Tyson says.

After that, the CFCP hopes that voters will approve Proposition 40. "A lot depends on the public's willingness to increase the frequency of funding," Tyson says.

Other funding mechanisms include private foundations, local bond issues and local taxes. For instance, Marin County allocates part of its property tax to Marin Agricultural Land Trust, and Sonoma County has a unique quarter-cent sales tax dedicated partly to protecting farmland around city edges. The Packard Foundation funds agricul-

Funding sources for agricultural easements have increased in recent years in California, although only a small portion of the state's farmland is protected using this technique. The 75-acre Oken property, foreground, was purchased by the Sonoma County Agricultural Preservation and Open Space District as a "community separator." Development rights were targeted strategically to create a greenbelt and prevent leapfrog development between Santa Rosa and Rohnert Park, background. 
tural easements as does the Great Valley Center's Agricultural Transactions Program, which is initially awarding $\$ 5.7$ million for farmland protection in three counties (Merced, Stanislaus and Yolo).

\section{Strategic placement}

Despite their growing popularity, easements still play a relatively small role in protecting farmland. "They're not significant in any way right now," says John Gamper of the California Farm Bureau Federation.

Statewide, there are only an estimated 120,000 acres in agricultural conservation easements, Sokolow says (see p. 15). Far more farmland enjoys shorter-term protection. More than 16 million acres are protected under the 1965 Williamson Act (which entails a 10-year commitment not to develop) and more than 400,000 acres are protected under the 1998 Farmland Security Zone program (which entails a 20-year commitment not to develop), Gamper says (see p. 13).

But numbers don't tell the whole story. The permanent protection afforded by agricultural easements is generally not needed for most of California's roughly 27 million acres of farmland. "Opportunities for turning rural land into residential land and other urban uses are generally confined to the fringes of expanding cities and other urban areas," Sokolow says. "Most California farmland is located far from the urbanizing fringes." Accordingly, the CFCP targets farmland that is at risk for development in the next 10 to 20 years.

Furthermore, well-planned agricultural easements can have a disproportionate effect that belies their small size. The CFCP targets farmland sites than can shield a much greater area from development. "Beyond a certain combined area, easements can be too expensive for urban infrastructure to leapfrog past," says the CFCP's Tyson. For instance, the nearly 2,000-acre set of easements bordering Cache Creek in Yolo County will probably curtail urban growth into prime farmland north of Woodland, he says.

Optimizing the size and placement of easements would be easier if planning were coordinated, farmland protection advocates say. That in turn depends on knowing the locations of existing easements, which is difficult because they are held by several dozen agencies and land trusts (see p. 9). To help local land-use planners choose the best sites, the state Farmland Mapping and Monitoring Program is working with the CALFED Bay-Delta Program to map agricultural easements in the Sacramento-San Joaquin watershed. (This project receives funding from Proposition 13, the $\$ 2$ billion water bond passed in 2000.)

In addition, in 2002, Sokolow will work with American Farmland Trust (AFT) on national study of agricultural easement locations; AFT is a national farmland protection organization with a significant California presence.

\section{Overcoming barriers}

Currently, the use of agricultural conservation easements in California is limited in part by farmers' lack of knowledge and understanding (see p. 21). "There's a fear factor that once you sign an easement, someone will tell you how to farm," Gamper says. In addition, some farmers are leery of signing away development potential in perpetuity, while others simply don't know that the option exists. The keys to increasing farmers' confidence include expanding the CFCP's outreach and establishing more local farmer-organized agricultural land trusts, Gamper says.

The CFCP's Tyson agrees, adding that the dearth of agricultural land trusts also limits the use of easements in California. Local governments need to have farmland conservation programs with funding to implement and monitor the easements - but only about 12 of the more than 110 land trusts in California focus exclusively or primarily on farmland.

"Cities and counties are underusing the CFCP program," Tyson says. "Large areas of the state are not served by agricultural land trusts," including Southern California and much of the agriculturally rich Central Valley (see pg. 22). For counties without them, "the American Farmland Trust can fill the void," Tyson says. "But there's less sense of local ownership. Local land trusts are good for farmer buy-in."

These issues notwithstanding, people on all sides of California agriculture support the concept of agricultural easements. "I don't think there's any other way to save farmland," says Jerry Meral, executive director of the Planning and Conservation League, a statewide nonprofit organization. "Lots of farmers out there would happily sell their development rights. We need more funding."
- Robin Meadows 


\section{Case study: Marin easements and local land-use planning}

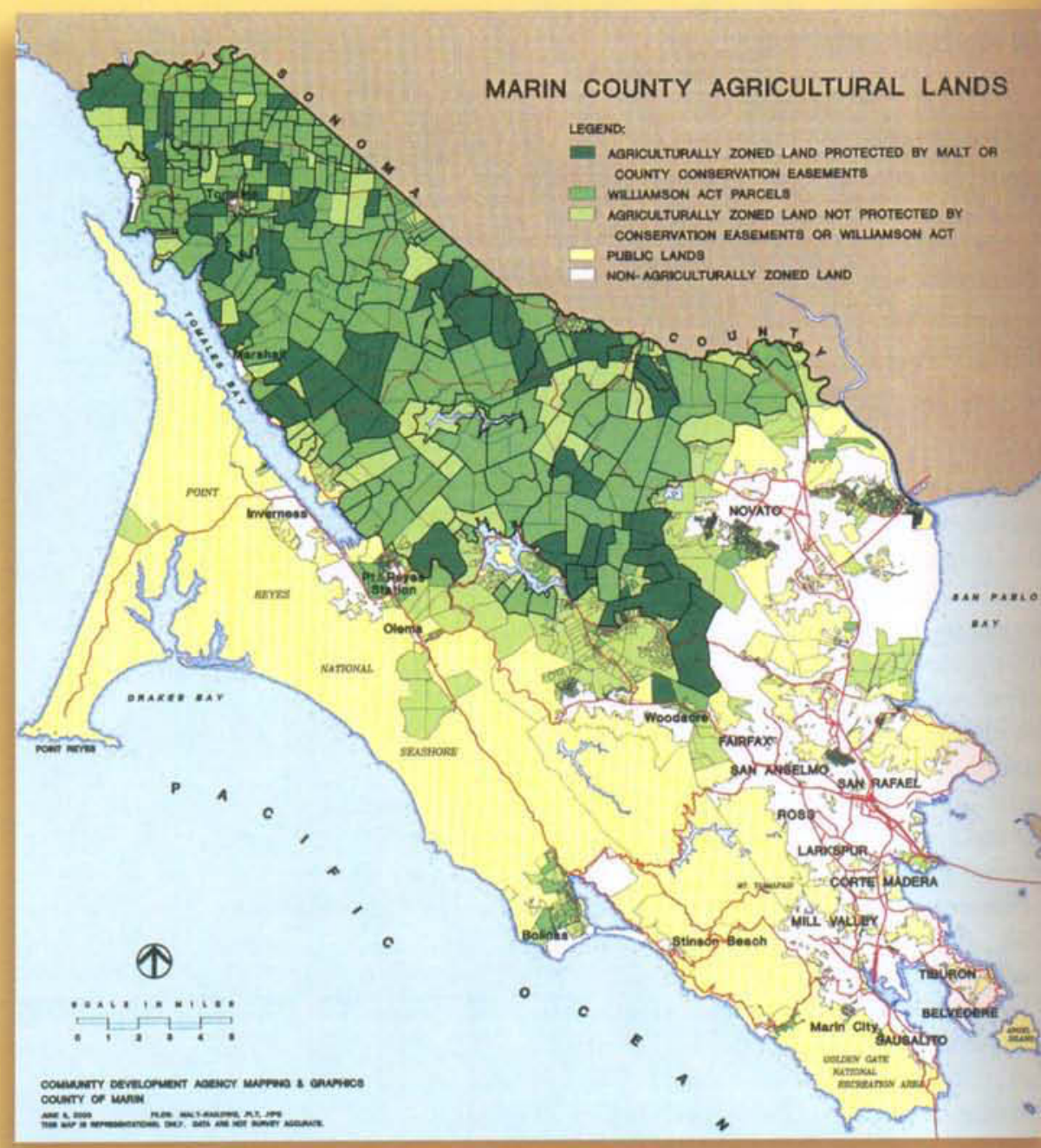

Depending on their location, agricultural easements can work closely with local government land-use planning to influence the pattern of urban growth in a community. In this map of Marin County, all 45 easements on 30,000 acres of dairy and ranch land - acquired by Marin Agricultural Land Trust (MALT) since its first transaction in 1983 - are located in Marin's rural agricultural corridor, an area identified for preservation in the county government's general plan during the late 1970 s. The easements support the plan by helping block the expansion of urban growth from the eastern corridor, where the county's cities are situated along Highway 101, and by impeding the building of rural residences for nonfarmers on agricultural parcels. With several large blocks of ranchland currently covered, MALT's easement acquisitions are gradually filling in the county's agricultural area.

MALT's experience is not, however, the norm for California land trusts. As independent nonprofit organizations with grassroots origins, land trusts generally operate at an organizational and political distance from local governments; this independence can cause tension between a trust's easement acquisitions and county and city land-use policies.

\section{Editor's note:}

In this special section, $U C$ researchers explore a new application of an old landpreservation tool: conservation easements specifically utilized to protect California agriculture and farmland (see map at left).

The articles are based on a project begun in 1998, which consisted of three separate studies: (1) the motivations and experiences of farmland owners in three counties who sold easements; (2) the accomplishments, strategies, organization, funding and planning relationships of local easement programs; and (3) the prospects for the extensive use of easements in the Central Valley.

Semistructured, open-ended interviews were the principal data collection technique. Interviews were conducted with: 46 landowners in Marin, Sonoma and Yolo counties; the managers and other leaders of 34 local conservation organizations; and more than 110 community leaders in 11 Central Valley counties. The project also collected data such as budgets, program brochures and newsletters of conservation organizations.

The principal investigator is Alvin D. Sokolow, UC Cooperative Extension public policy specialist in the Department of Human and Community Development at UC Davis, and associate director for rural-urban issues of the UC Agricultural Issues Center. Research colleagues were Ellen Rilla, UCCE director in Marin County, and consultants Cathy Lemp and Robin Kozloff. Currently nearing completion, this research was supported by the Great Valley Center through a grant from the Land Conservation Office of the California Department of Conservation.

The UC Agricultural Issues Center published the first study report, California Farmers and Conservation Easements: Motivations, Experiences and Perceptions in Three Counties, in December 2000. Several related reports are forthcoming. 